Original Research Paper

\title{
Identifying Nutrient Contributors in North Carolina's Coastal Plain Blackwater Rivers
}

\author{
${ }^{1}$ Narayan B. Rajbhandari, ${ }^{2}$ Sushama Pradhan, ${ }^{3}$ Mauro Di Luzio, ${ }^{1}$ Adugna Kebede and ${ }^{1}$ Virginia Baker \\ ${ }^{I}$ NC DENR, Division of Water Resources, 512 North Salisbury Street, Raleigh, NC 27604, USA \\ ${ }^{2}$ NC DHHS, On-site Water Protection Branch, 5606 Six Forks Road, Raleigh, NC, USA \\ ${ }^{3}$ Texas Agri. Life Blackland Research and Extension Center, 720 East Blackland Road, Temple, TX 76502, USA
}

Article history

Received: 30-03-2015

Revised: $13-08-2015$

Accepted: 21-09-2015

Corresponding Author:

Narayan B. Rajbhandari

NC DENR, Division of Water

Resources, 512 North Salisbury

Street, Raleigh, NC 27604, USA

Email: narayan.rajbhandari@ncdenr.gov

\section{Introduction}

Discharge of excess nutrients from upstream river watersheds into an estuary and its coastal area can reduce dissolved oxygen levels, thereby killing marine organisms (Mallin, 2000). Several studies have indicated that anthropogenic loads and the resulting eutrophication are the two major sources of nutrient loads in the blackwater river watersheds located in the Southeastern coastal plain of the United States, from Virginia south to northern Florida and in areas of the Gulf Coast (Mallin et al., 1997; Cahoon et al., 1999; Moran et al., 1999; Seitzinger et al., 2002; Graves et al., 2004; Hendrickson et al., 2007).

Blackwater Rivers are characteristically low gradient and flowing slowly through extensive flood plains, forested swamps and wetlands (Meyer 1990; Smock and
Gilinsky, 1992). As vegetation, animals and microorganisms decay in water, organic matter consisting largely of fulvic acids are leached out to the river. Since surface soils in the coastal plains are mostly sandy and have a low capacity for sorption of organic matter, the decomposed organic matter remains soluble in water, resulting in transparent water that is darkly stained, resembling tea or coffee (Meyer, 1990). Hence the water body is called blackwater. Owing to major shifts in land uses in some blackwater watersheds, a large portion of Nitrogen (N) and Phosphorus (P) are retained within the colored decomposed organic matter (Graves et al., 2004).

Since 1996 a portion of Lower Cape Fear River (LCFR), from Toomers Creek to Snows Cut (2,273 hectares), has been on North Carolina's 303(d) list of impaired waters for low Dissolved Oxygen (DO) 
violations (NCDENR, 2007). Sources of low DO levels include natural and anthropogenic sources of oxygen consuming nutrients from the upstream blackwater rivers, such as: LCFR, Black River and Northeast Cape Fear River (NECFR). Several studies indicate that N and $\mathrm{P}$ addition to blackwater rivers due to land uses support algal blooms during selected period and stimulated growth of heterotrophic macroflora, which becomes source of labile biochemical oxygen demand and oxygen deficit (Mallin et al., 2001; Seitzinger et al., 2002). As a follow up to these studies, a watershed model based assessment was conducted to determine $\mathrm{N}$ and $\mathrm{P}$ loads entering the LCFR from a large blackwater river under different land use scenarios, including large-scale agricultural operations, intensive swine operations and conventional point-source discharges.

In this study $\mathrm{N}$ and $\mathrm{P}$ were chosen as key parameters due to the fact that they are the primary nutrient-limiting factors for plant, algal and microbial production in coastal systems. Higher concentration of these nutrients leads to oxygen deficit in the aquatic systems. A watershed model, Soil and Water Assessment Tool (Winchell et al., 2009), was used to perform systematic analysis of these nutrient parameters to support the water quality evaluation and management plans for the LCFR watershed in North Carolina. SWAT model is a wellestablished watershed scale hydrologic model which has been used in numerous water quality assessment studies worldwide (Borah, et al., 2006; Busteed et al., 2009; Jha et al., 2007; Kirsh et al., 2002; Ouyang et al., 2008; Niraula et al., 2012; Veith et al., 2005).

\section{Materials and Methods}

\section{Study Sites}

This study was conducted in Northeast Cape Fear River (NECFR) watershed in North Carolina. This river exhibits the typical blackwater characteristics (Mallin et al., 2001) and occupies approximately 438,522 ha (1,693 square miles) of the LCFR watershed (Fig. 1). The watershed encompasses the two coastal plain counties: Duplin at the northern part and Pender at the southern part of the watershed. According to the 2007 agricultural statistics (NCDA\&CA, 2007), Duplin County has included substantial part of swine operations in the Cape Fear River Basin since 1997. Most of the agricultural lands in the watershed were used for land spreading of hog waste, which contains large quantities of both organic and inorganic nitrogen and phosphorus (Mallin et al., 1997). In addition, significant deposits of organic nutrients and low DO levels characterize wetlands in the watershed.

In the NECFR watershed nonpoint sources are comprised of agricultural land (32.74\%), forested land $(26.62 \%)$, range land/cattle field $(4.79 \%)$, forested wetland $(30.11 \%)$, non-forest wetland $(0.66 \%)$, urban land $(1.50 \%)$, developed open space $(3.00 \%)$ and barren land (0.12). Urban land includes residential, road and parking lots. Residential development is mostly concentrated at the lowermost part of the watershed. Developed open space mostly consists of vegetation in the form of lawn grasses, gulf course, erosion control area and parks. The remaining land consists of water body $(0.40 \%)$.

In this watershed, most of the farmers practice hog farming and hay cultivation. A few farmers plant corn, soybean and wheat but most of the cropping lands had been converted to Bermuda grass lands for hog farming. During the study period, approximately 571 hog farms were identified in the watershed from the North Carolina Division of Water-Resources (NCDWR) permit records, most of which are located in Duplin County (Fig. 1). Large quantity of hog waste was often sprayed on the Bermuda grasslands. In general, the hog waste was sprayed on Bermuda grasslands from March through September and small grain fields from September through March. The permitted amount of hog waste application rate varies with crop type, soil type, land slope and county. On an average, hog waste applied on agricultural lands was estimated to be $350-400 \mathrm{~kg}$ per hectare per year (Sloan et al., 1999).

Based on the 2002 agricultural census conducted by Natural Services Conservation Service (NRCS) all rangelands in the NECFR watershed were assumed to be populated with approximately 23,000 beef/cattle. Following the Agriculture Waste Management Field Handbook (USDA, 2004), it was estimated that one cattle added $2.3 \mathrm{~kg} \mathrm{ha}^{-1}$ dry manure to the land each day for 240 consecutive days. Since the majority of the cattle were grazed at rangelands in the watershed, the estimated manure rates were applied to the rangelands only.

In additions, there were 31 different conventional point sources contributing nutrient directly to the NECFR. Nutrient discharges from these point sources are regulated under National Pollutant Discharge Elimination System (NPDES) programs in the NECFR watershed. These point sources contributed $416 \mathrm{~kg} \mathrm{day}^{-1}$ of $\mathrm{TN}$ (sum of organic nitrogen, ammonia, nitrate and nitrite) and $134 \mathrm{~kg} \mathrm{day}^{-1}$ of TP (sum of organic phosphorus and mineral phosphorus) during the study period.

While developing the SWAT model, TN was estimated to be comprised of $5 \%$ organic nitrogen and $95 \%$ of nitrate nitrogen and nitrite nitrogenin point source discharged waters. Ammonia was considered to be negligible unless it was reported in the NPDES report to the North Carolina Division of Water Resources (NCDENR). Likewise, TP was estimated to be comprised of $30 \%$ organic phosphorus and $70 \%$ mineral phosphorus. (Source: NPDES database and personal communication with a point source export in the DWR, Mr. Mike Templeton). 


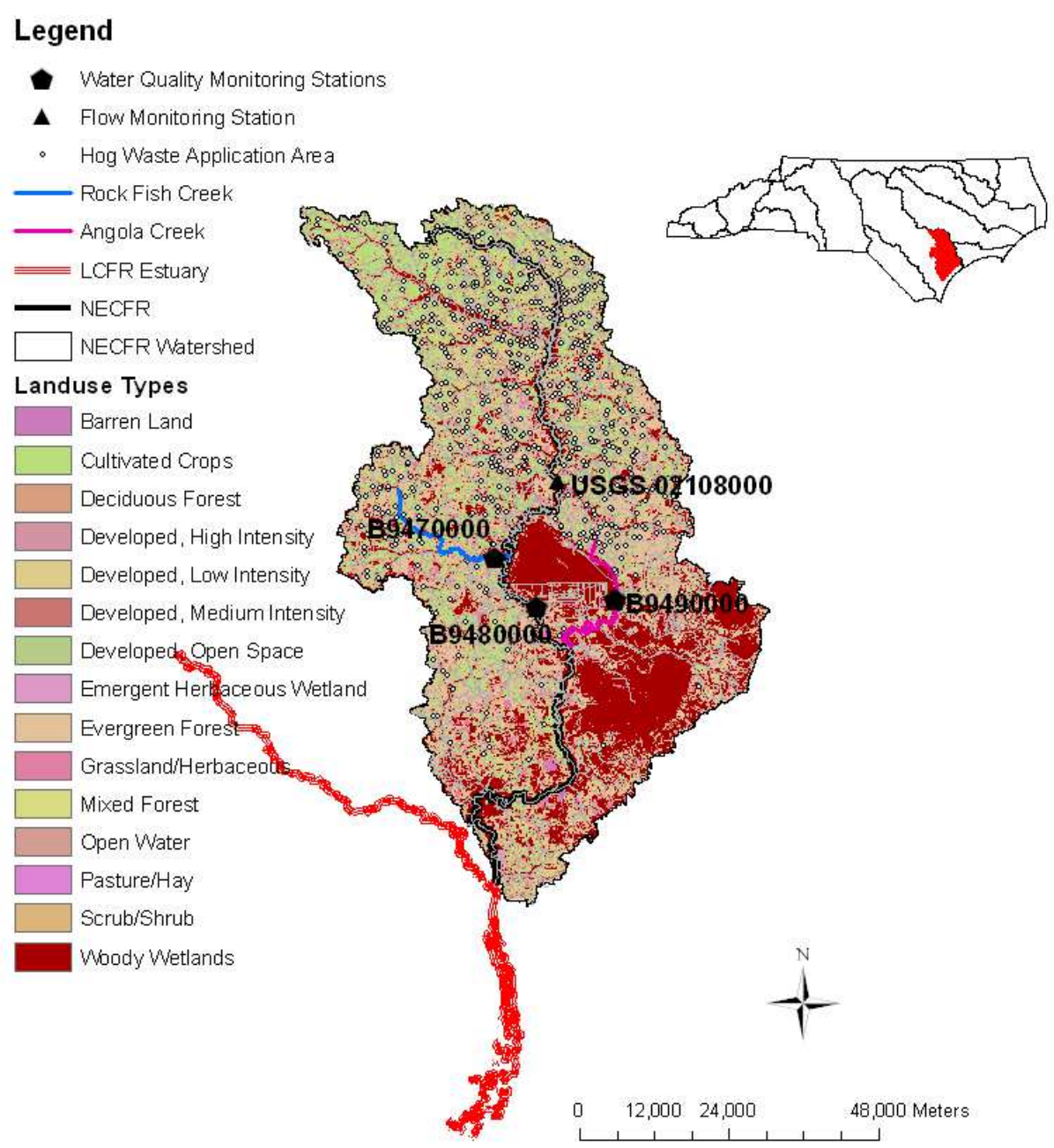

Fig. 1. Northeast cape fear watershed showing selected water quality and flow stations, hog farm sites and land use distribution

\section{Model Selection and Dataset Used}

The SWAT model was selected for this study because of its capability to assess $\mathrm{N}$ and $\mathrm{P}$ loadings from point and non-point sources in a large watershed with varying land uses and management conditions (Arnold et al., 1998). The model is a physically based distributed-parameter simulation model that enables the user to simulate runoff and pollutant transport processes up to 100 years. This model can be used to study large watersheds with up to two thousand square miles area. The model has the capability to divide watersheds into hundreds of sub-basins and thousands of Hydrologic Response Units (HRUs).

The NECFR watershed was delineated into 23 subbasins using the stream coverage Reach File (USGS 1:24000 topographic maps) and Digital Elevation Model $(\mathrm{DEM})$ maps $(30 \times 30 \mathrm{~m})$ to estimate watershed parameters. These include stream length, stream slope, stream dimensions, overland slope, slope length,
Manning's $\mathrm{n}$, soil erodibity factor $\mathrm{K}$, management practice factor $\mathrm{P}$ and crop factor $\mathrm{C}$. The delineated subbasin map was then overlaid with land use (2000 LANDSAT satellite imagery-USGS, 2005) and soil maps to identify 678 HRUs and the respective parameters, including bulk density, soil layer, available water, hydraulic conductivity and texture type (U.S. STATSGO database-USGS, 2007). In SWAT, each sub-basin can be characterized by eight major model components; hydrology, weather, sedimentation, soil temperature, plant growth, nutrients, pesticides and land management.

Climate data inputs are critical to watershed model simulation. Daily air temperature and precipitation data for the study periods (1999-2005) were acquired through the State Climate Office of North Carolina for the nearby weather stations of Warsaw, Wallace, Willard and Wilmington. These weather stations are located within NECFR watershed. Wind speed and 
solar radiation were simulated using the weather generator built-in SWAT. The amount of rainfall in the area during 2000 through 2002 was less than the long-term mean annual rainfall of $1,378 \mathrm{~mm}$ (54 inches) (Table 2). According to the National Air Deposition Program (UIUC, 2007), rainfall carried approximately $1.3 \mathrm{mg} \mathrm{L}^{-1}$ of $\mathrm{N}\left(0.43 \mathrm{mg} \mathrm{L}^{-1}\right.$ of NH4 and $0.83 \mathrm{mg} \mathrm{L}^{-1}$ of NO3) in the NECFR watershed during the study period.

\section{Model Calibration}

The model was run from 1997 to 2005 for daily outputs. Considering warm-up period for the first two year the model estimated outputs from 1999 to 2005 were utilized for calibration off low, Suspended Sediment Concentration (SSC), Total Nitrogen (TN) and Total Phosphorus (TP). Since the SWAT model does not simulate tidal effects, calibration was not carried out at the outlet of the watershed where there are frequent tidal effects. Instead the calibration was carried out at the USGS Station, 02108000, for flows and the NCDWR ambient monitoring station, B9480000, for the water quality constituents (Fig. 1). Flow was recorded daily at the USGS Station, whereas the nutrient concentrations were recorded monthly during the study periods.

The terms Total Suspended Solids (TSS) and SSC are often used interchangeably in literature to describe concentration of the total suspended solid phase in a water column. However, these two terms are considered different in this study due to fact that the TSS analytical method does not include all sand particles. Therefore, in order to match the observed TSS with the model estimated sediment concentration, which includes the entire water-sediment mixture, the SSC was estimated using Equation 1. As suggested by Glysson et al. (2004), caution should be used in using the equation, especially to correct TSS values less that above $500 \mathrm{mg} \mathrm{L}^{-1}$. The equation was, therefore, tested with original TSS data collected at the station B9480000 (Fig. 1) by assigning different suggested intercept values from 12.4 to $103 \mathrm{mg} \mathrm{L}^{-1}$ (Glysson et al., 2004). The value of 32 was found to be adequate to estimate correct TSS data for the watershed:

$$
S S C=32+1.0857 \text { TSS }
$$

For flow calibration, the SWAT model estimates representative Curve Number (CN) values for various land covers and soil types. The default values as estimated by the model for all the HRUs were reduced by $10 \%$ to reflect existing hydrologic condition in the NECFR watershed. The Muskingum method was used for simulating the channel routing process and the Hargreaves method for estimating potential evapotranspiration. In addition, other sensitive parameters for surface and ground water processes were adjusted during calibration as presented in Table 1. The initial nutrient concentrations for soils were formerly measured for the Orangeburge Loamy Sandy Soil in Duplin County, where swine operations were substantially practiced. Since the watershed encompasses the county in its northern part, the initial nutrient concentrations in soils were applied in almost half the upper watershed, above the ambient station B9480000, where hog farms were heavily and evenly distributed. Similarly, the initial concentrations in ground water were applied in the hog farming part of the watershed. The initial concentrations were estimated based on quarterly measurement from March 1998 through November 1999 at the Abertson site in Duplin County.

\section{Performance Evaluation of Model}

Model performance was evaluated through qualitative and quantitative measures, involving both graphical comparisons and statistical tests. For flow simulations where continuous records were available, both the qualitative and the quantitative techniques were adopted for the calibration station. However, the performance was not evaluated for daily flows due to some flow inconsistencies associated with localized rainfall distributions in the NECFR watershed. Therefore, model performance was assessed only for total monthly flow. For water quality constituents, the model performance evaluation was carried out based primarily on visual and graphical presentations as the frequency of observed data is inadequate for accurate statistical comparisons. However, annual mean of the observed values were compared with annual mean of the predicted values using paired t-test.

Statistical test such as Paired-Difference t-test, Nash-Sutcliffe model efficiency (NS), Coefficient of Determination (R-Square), Root Mean Square Error (RMSE) for mean and Relative Error (RE) were used to evaluate model prediction for flow. PairedDifference t-test was employed to assess whether the average difference between observed and model predicted values was significantly different from zero. If the difference was not significantly different from zero, then the model prediction was considered to be acceptable. The NS was employed to quantitatively evaluate model performance. This value can range from negative infinity to 1 . The NS values greater than 0.75 were considered "good" (Moriasi et al., 
2007). When the NS coefficients are 0 or less, model predictions are no better than the mean of the observed data over the evaluation period. The RSquare value was employed to evaluate relationship between observed and predicted values. If the RSquare value is close to one, then the model prediction is considered acceptable. The error measurements were employed to indicate the difference between observed and simulated values relative to the observed data. If the RMSE and RE values are close to zero, then the model prediction is considered satisfactory. The United State Environmental Protection Agency's Technical Guidance Manual for performing Estuary Waste Load Allocations proposes acceptable error statistic criteria of $45 \%$ for nutrient parameters (USEPA, 1999).

Table 1. Parameters used for model calibration

\begin{tabular}{|c|c|c|}
\hline Parameters & Calibration value & Sources \\
\hline \multicolumn{3}{|l|}{ I. Hydrologic Parameters } \\
\hline \multicolumn{3}{|l|}{ A. Evaporation } \\
\hline 1. Soil Evaporation Compensation Factors (ESCO) & 0.95 & Neitsch et al. (2002) \\
\hline 2. Plant Evaporation Compensation Factor (EPCO) & 1.00 & \\
\hline \multicolumn{3}{|l|}{ B. Ground Water } \\
\hline 1. Re-Evaporation Coefficient (GW REVAP) & 0.1 & Neitsch et al. (2002) \\
\hline 2. Deep Aquifer Percolation Factor (RCHRG_DP) & 0.1 & \\
\hline \multicolumn{3}{|l|}{ C. Manning's n for Overland Flow } \\
\hline 1. Developed Land & 0.1 & Neitsch et al. (2002) \\
\hline 2. Pasture Land & 0.4 & \\
\hline 3. Forested Land & 0.6 & \\
\hline \multicolumn{3}{|l|}{ II. Chemical Parameters } \\
\hline \multicolumn{3}{|l|}{ 1. Nitrogen Percolation Coefficient (NPERCO) 0.90} \\
\hline 2. Phosphorus Percolation Coefficient (PPERCO) & 10.00 & Neitsch et al. (2002) \\
\hline 3. Phosphorus Portioning Coefficient (PHOSKD) & $100 \mathrm{~m}^{3} / \mathrm{mg}$ & \\
\hline 4. Residue Decomposition Coefficient (RSDCO) & 0.10 & \\
\hline 5. Phosphorus Sorption Coefficient (PSP) & 0.015 & \\
\hline 6. Biological Mixing Efficiency (BIOMIX) & 0.40 & \\
\hline \multicolumn{3}{|l|}{ III. Physical Parameters } \\
\hline 1. Fraction Of Algal Biomass That Is Nitrogen (AI1) & 0.090 & Neitsch et al. (2002) \\
\hline 2. Fraction Of Algal Biomass That Is Phosphorus (AI2) & 0.020 & \\
\hline \multicolumn{3}{|l|}{ IV. Upper Soil Layer ${ }^{1}$} \\
\hline 1. Nitrate & $5 \mathrm{mg} \mathrm{kg}^{-1}$ & Shah et al. (2006) \\
\hline 2. Organic Nitrogen & $920.00 \mathrm{mg} \mathrm{kg}^{-1}$ & \\
\hline 3. Soluble Phosphorus & $4 \mathrm{mg} \mathrm{kg}^{-1}$ & \\
\hline 4. Organic Phosphorus & $313 \mathrm{mg} \mathrm{kg}^{-1}$ & \\
\hline \multicolumn{3}{|l|}{ V. Ground Water ${ }^{1}$} \\
\hline 3. Nitrate & $8.65 \mathrm{mg} \mathrm{L}^{-1}$ & Dahlen and Milosh (2002) \\
\hline 4. Soluble Phosphorus & $0.20 \mathrm{mg} \mathrm{L}^{-1}$ & \\
\hline
\end{tabular}

${ }^{\mathrm{T}}$ Values are applied to the upper part of the watershed, above the ambient station B9480000 (Fig. 1), where hog farms are heavily and almost evenly distributed

Table 2. Statistical measures to compare model simulation and observed flow at USGS 02108000 during the study period 1999 2005

\begin{tabular}{|c|c|c|c|c|c|c|c|c|c|}
\hline \multirow[b]{2}{*}{$\begin{array}{l}\text { Simulation } \\
\text { year }\end{array}$} & \multirow[b]{2}{*}{$\begin{array}{l}\text { Total } \\
\text { Rainfall } \\
(\mathrm{mm})\end{array}$} & \multicolumn{2}{|c|}{ Mean Flow $\left(\mathrm{m}^{3}\right.$ month $\left.^{-1}\right)$} & \multirow{2}{*}{$\begin{array}{l}\text { Standard error } \\
\text { for mean } \\
\text { difference } \\
\left(\times 10^{7}\right)\end{array}$} & \multirow[b]{2}{*}{$P>|t|$} & \multirow[b]{2}{*}{ NS } & \multirow[b]{2}{*}{$\mathrm{R}^{2}$} & \multirow[b]{2}{*}{ RMSE } & \multirow[b]{2}{*}{$\mathrm{RE}$} \\
\hline & & $\begin{array}{l}\text { Simulated } \\
\left(\times 10^{7}\right)\end{array}$ & $\begin{array}{l}\text { Observed } \\
\left(\times 10^{7}\right)\end{array}$ & & & & & & \\
\hline 1999 & $1,851.38$ & 11.76 & 10.79 & 1.20 & 0.430 & 0.92 & 0.92 & 0.40 & 0.09 \\
\hline 2000 & $1,360.09$ & 4.89 & 5.31 & 0.52 & 0.420 & 0.66 & 0.76 & 0.35 & 0.08 \\
\hline 2001 & $1,018.86$ & 3.30 & 3.45 & 0.42 & 0.720 & 0.84 & 0.85 & 0.42 & 0.04 \\
\hline 2002 & $1,267.63$ & 4.09 & 2.82 & 0.29 & 0.001 & 0.61 & 0.85 & 0.59 & 0.45 \\
\hline 2003 & $1,763.52$ & 8.94 & 9.54 & 0.82 & 0.480 & 0.76 & 0.81 & 0.30 & 0.30 \\
\hline 2004 & $1,341.03$ & 5.55 & 4.82 & 0.53 & 0.200 & 0.27 & 0.44 & 0.41 & 0.15 \\
\hline 2005 & $1,455.02$ & 3.66 & 4.18 & 0.45 & 0.270 & 0.62 & 0.77 & 0.39 & 0.12 \\
\hline Over All & $1,436.79$ & 6.02 & 5.85 & 0.26 & 0.480 & 0.89 & 0.88 & 0.40 & 0.31 \\
\hline
\end{tabular}




\section{Results and Discussion}

\section{Flow Calibration}

Stream flows were calibrated by comparing simulated stream flows and observed stream flows at the USGS station 02108000 for the study period spanning from 1999-2005. Figure 2 illustrates the time series plot of the monthly observed flows and the model predicted flows. The model simulated the magnitude and trend of flows well in this watershed. Average simulated and observed flows were not significantly different at 0.05 confidence level, except 2002 (dry year) where the model simulated higher flows (Table 2). As a result RMSE was estimated slightly higher for 2002. In addition, the model simulated slightly higher flows during 2004, resulting lower values of R-Square and NS. However, the model predicted monthly averaged flows $\left(6.02 \times 10^{7} \mathrm{~m}^{3}\right)$ were closer to the observed flows $(5.84$ $\left.10^{7} \times 10^{7} \mathrm{~m}^{3}\right)$. Further agreement between observed and simulated flows was shown by high R-Square value $(0.88)$ and NS value $(0.89)$. Additionally, the low error values associated with the model prediction further confirmed the agreement. It should be noted that there were some daily flow inconsistencies associated with localized rainfall distributions in the NECFR watershed.

\section{Nutrient Calibration}

Field data collected at the NCDWQ ambient monitoring station (B9480000) was used to calibrate model simulated sediment, TN and TP concentrations. The simulated and predicted sediments, TN and TP are presented in Fig. 3 to 5, respectively. The distribution plot for sediment and TN indicated that the monthlyobserved values were within the interquartile range of daily-predicted values in each month, suggesting that the model simulated concentrations were close to the observed concentrations during the calibration period. For TP, the simulated concentrations were also within the range of daily predicted concentrations, except during January through March (Fig. 5). The concentrations were slightly under predicted during the first three months

Overall, the analysis of variance results indicated that average model predicted values for all studied parameters were not significantly different from the field observed values $(p>0.05)$. The predicted overall concentration of sediment, TN and TP were $36.3,1.3$ and $0.2 \mathrm{mg} \mathrm{L}^{-1}$, where the field observed values were $35.3,1.2$ and $0.2 \mathrm{mg} \mathrm{L}^{-1}$, respectively.

\section{Nutrient Contribution Assessment}

The calibrated SWAT model was used to assess nutrient contributions from point sources and nonpoint point sources. Details are provided below.

\section{Conventional Point Sources}

The SWAT model was run with and without conventional point sources from 1999 to 2005 to estimate averaged load delivered from point sources. The nutrient contributions from the point sources were estimated substantially lower than nonpoint sources. Conventional point sources contributed only $0.4,2.0$ and $3.0 \%$ of total sediment, TN and TP concentrations, respectively (Table 3 ). It appears that almost all sediment loads from point sources were deposited and more than $70 \%$ of the nutrients were lost due to physical and biological processes in receiving wetlands. Studies have shown that freshwater wetlands could retain more than $60 \%$ of $\mathrm{N}$ and $70 \%$ of P (Saunders and Kalff, 2001; Reddy et al., 1999). However, assimilation capacity of wetlands varies with site specific physical, biological and chemical conditions (Reddy et al., 1999; Johnston, 1991).

\section{Non-Point Sources}

Model predicted nonpoint sources sediments, TN and TP and sediments loadings from various land use types are presented in Table 3.

\section{Sediment}

Developed open spaces, agricultural lands and forest wetlands are the major sources of sediment loadings from the NECFR watershed to the LCFR, which cumulatively contributed $61,394.31$ tons per year. Although the developed open lands cover only $3 \%$ of the NECFR watershed, they contributed $35 \%$ of the total annual sediment load $(68,838.60$ tons). This could be because the open spaces in the watershed were comprised of impervious surface and erosion control areas. Since the SWAT model uses the USLE equation (Wischmeier and Smith, 1978), the combined effects of rainfall intensity factor (R) and crop cover factor (C) plays a significant role in estimating soil losses. High C value associated with open space would have enhanced soil erosion from the open spaces during high rainfall period. The $\mathrm{C}$ value is relatively low for agriculture lands due to Bermuda grass and hence soil loss from the agriculture lands appears to be 0.15 tons/ha as compared to 1.83 tons/ha from the developed open lands.

\section{Total Nitrogen}

Agricultural lands, forested lands and forested wetlands contributed a major portion of the load (Table 3 ). They respectively contributed approximately 28,20 and $33 \%$ of the TN load from the NECFR watershed to the LCFR. Forested wetlands covered comparable amount of land area to agricultural and forested lands, but they contributed relatively higher TN load. While forested wetlands are generally considered as sinks for nutrients, the findings of this study suggest that these 
wetlands acted as both sinks and sources for nutrients. The relatively higher contribution of nutrients from the forested wetlands in the NECFR watershed could be due to the following four reasons:

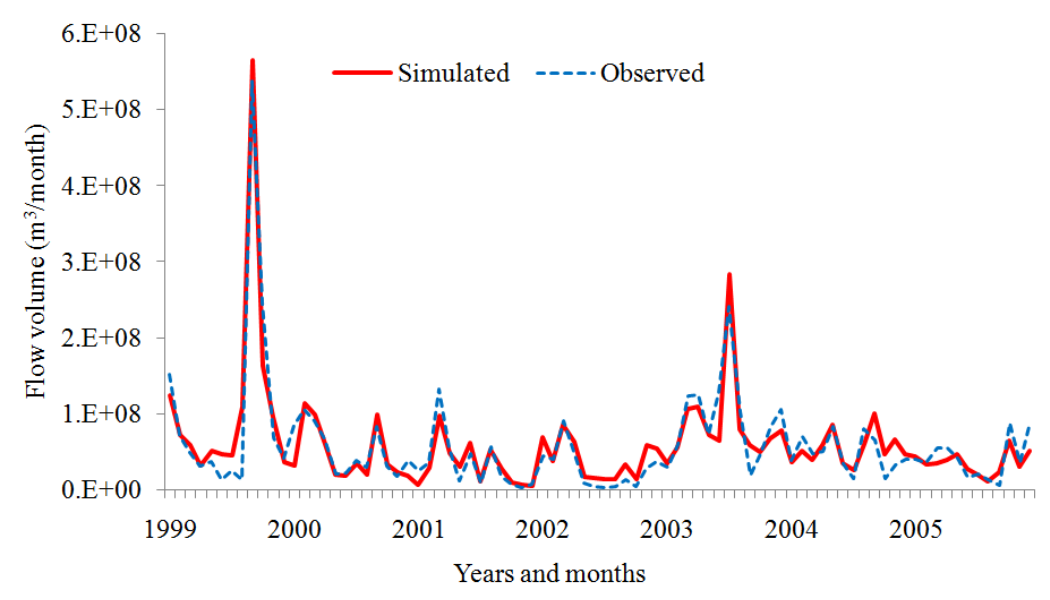

Fig. 2. Monthly total simulated and observed flow volumes at USGS 02108000

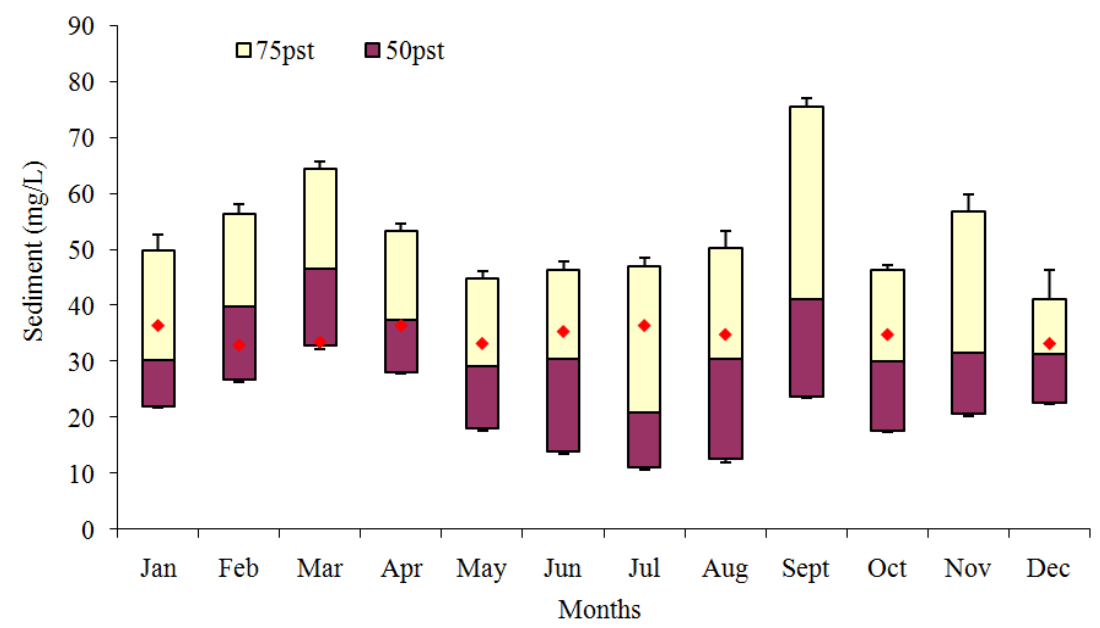

Fig. 3. Monthly observed concentration of suspended sediment Vs quantile distribution of predicted daily suspended sediment at ambient station B9480000

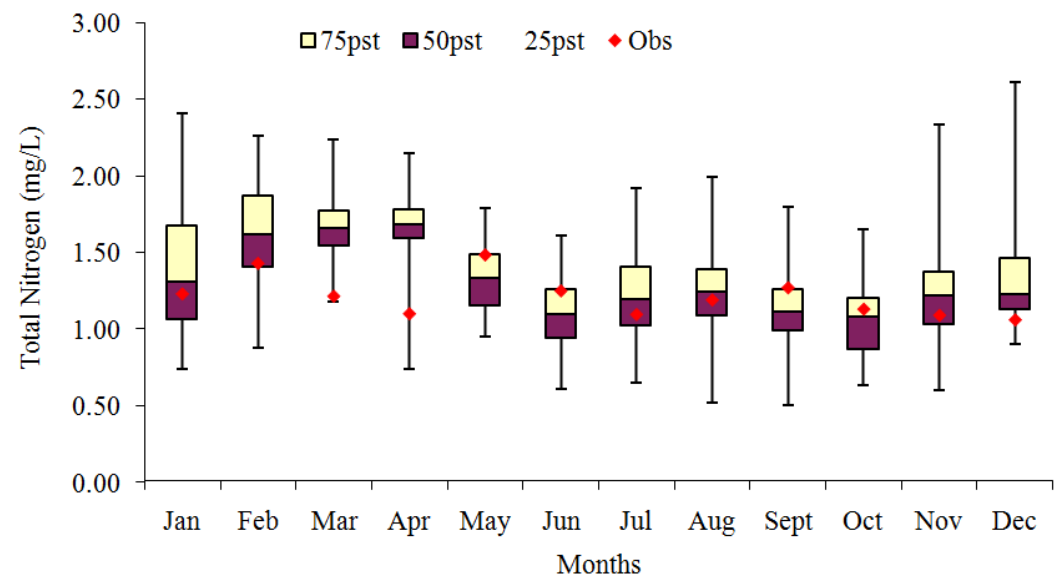

Fig. 4. Monthly observed concentration of total nitrogen Vs quantile distribution of predicted daily total nitrogen at ambient station B9480000 


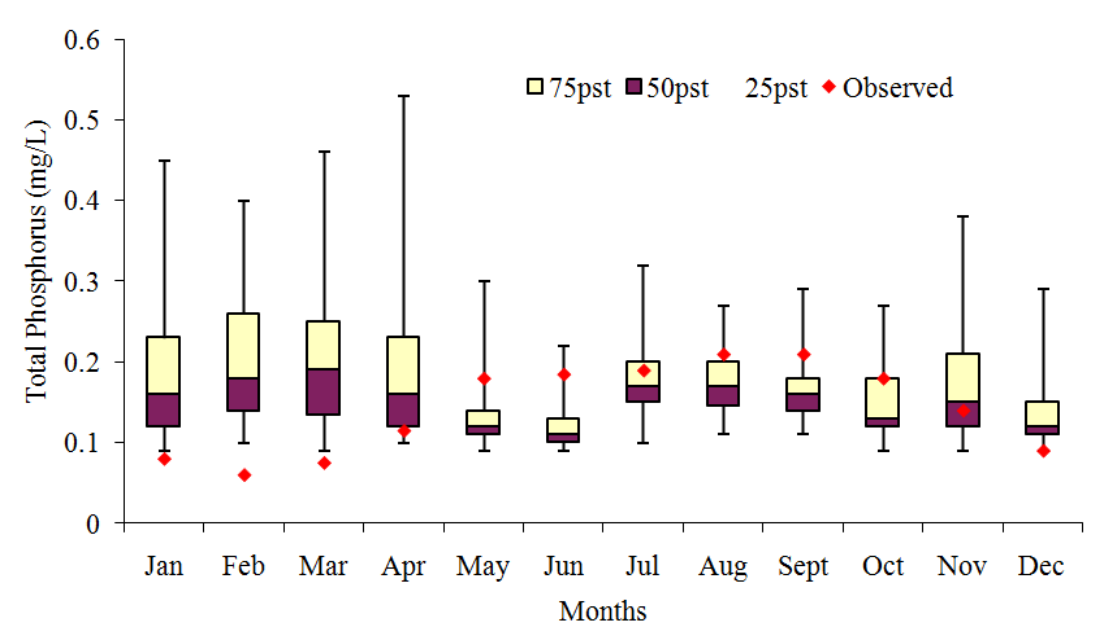

Fig. 5. Monthly observed concentration of total phosphorus Vs quantile distribution of predicted daily total phosphorus at ambient station B9480000

Table 3. Summary of simulated average annual pollutant loads delivered to the Lower Cape Fear River from different land-uses and point sources over the study period

\begin{tabular}{|c|c|c|c|c|c|c|c|c|}
\hline \multirow[b]{2}{*}{ Sources } & \multicolumn{2}{|l|}{ Area } & \multicolumn{2}{|l|}{ Sediment } & \multicolumn{2}{|l|}{$\mathrm{TN}$} & \multicolumn{2}{|l|}{ TP } \\
\hline & $\mathrm{km}^{2}$ & $\%$ & tons $\mathrm{yr}^{-1}$ & $\%$ & tons $\mathrm{yr}^{-1}$ & $\%$ & tons $\mathrm{yr}^{-1}$ & $\%$ \\
\hline Urban Lands & 65.94 & 1.51 & $1,648.97$ & 2.4 & 123.25 & 3.52 & 10.47 & 2.32 \\
\hline Developed Open land & $1,33.24$ & 3.05 & $24,420.68$ & 35.48 & 131.24 & 3.75 & 168.98 & 37.37 \\
\hline Agriculture & $1,435.54$ & 32.87 & $22,241.28$ & 32.31 & 979.55 & 28.01 & 142.40 & 31.49 \\
\hline Cattle Fields & 209.96 & 4.81 & $1,706.71$ & 2.48 & 315.32 & 9.02 & 10.19 & 2.25 \\
\hline Forest Lands & $1,167.42$ & 26.73 & $2,329.42$ & 3.38 & 706.66 & 20.21 & 18.33 & 4.05 \\
\hline Forest Wetlands & $1,320.37$ & 30.23 & $14,732.35$ & 21.40 & $1,146.86$ & 32.80 & 82.85 & 18.32 \\
\hline Non-forest Wetlands & 29.17 & 0.67 & 380.27 & 0.55 & 21.82 & 0.62 & 2.04 & 0.45 \\
\hline Baren Lands & 5.49 & 0.13 & $1,123.21$ & 1.63 & 8.59 & 0.25 & 3.81 & 0.84 \\
\hline Point Sources & & & 255.71 & 0.37 & 63.50 & 1.82 & 13.14 & 2.91 \\
\hline Total & $4,367.14$ & 100.00 & $68,838.60$ & 100.00 & $3,496.79$ & 100.00 & 452.20 & 100.00 \\
\hline
\end{tabular}

First, the forested wetlands in the watershed appear that they were not designed to trap nutrient loads coming from adjoining lands. The wetlands functioned as nutrient sources in natural environment, where several streams/creeks drain nutrients through them from adjoining lands. Some of the wetlands are located at the highest reaches of the watershed at the head of and/or in association with first and second order intermittent and perennial stream channels. These wetlands are commonly known as headwater wetlands. Savage and Baker (2007) found that headwater wetlands located in upper reaches of natural watersheds do not have a better filtering capacity than headwater wetlands located in upper reaches of urban and developed watersheds in North Carolina coastal lands. They also concluded that headwater wetlands located in the more urban and highly agricultural watersheds, where hog farming are the prime concern, have lower water quality than wetlands in more natural areas in regards to nitrate and nitrite.

Second, dry biomass accumulation in the forested wetlands were second highest (8.84 tons $\mathrm{ha}^{-1} \mathrm{yr}^{-1}$ ) after the forested lands (Table 4), suggesting more Organic Nitrogen $(\mathrm{ON})$ pool is available in the wetland soils of the NECFR watershed. The model prediction is further justified by the actual measured ON concentration during 2004 and 2005 at the ambient stations -B9490000 and B9470000 (Fig. 1). The station B9490000 was located in Angola Creek which flows through forested wetland; whereas the station B9470000 was located in Rock Fish Creek which flows through mixed land uses where agriculture and forested lands dominate the scenario. Organic Nitrogen concentration in Angola Creek remained substantially higher than in Rock Fish Creek throughout the years (Fig. 6). The result suggests that forested wetlands are comparatively critical sources of $\mathrm{ON}$ in the NECFR. It appears that mineralization of the $\mathrm{ON}$ was poor in the wetland sediment due to their sandy soils having a low capacity for sorption of organic matter. As a result the decomposed organic matter remained soluble in water. 


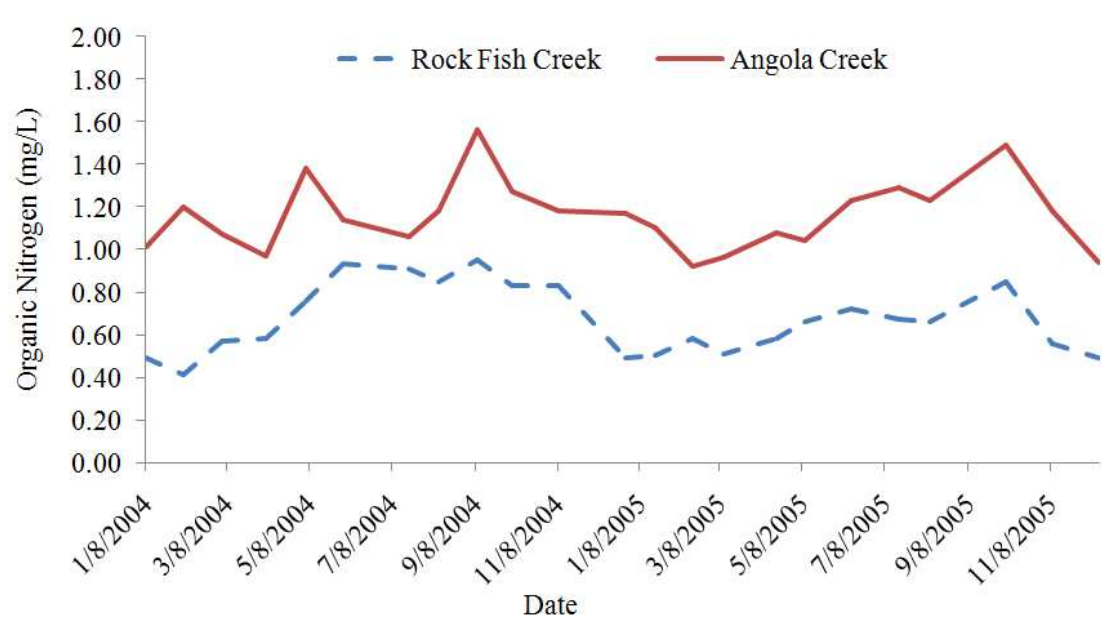

Fig. 6. Attenuation of nitrogen in streams flowing through forested wetland (Angola Creek at B9490000) and Mixed lands (Rock Fish Creek at B9470000) during 2004 and 2005

Table 4.Simulated nutrient dynamics at various land-use conditions

\begin{tabular}{lcccc}
\hline Land use types & $\begin{array}{l}\text { Total biomass dry } \\
\text { tons ha } \mathrm{yr}^{-1}\end{array}$ & $\begin{array}{l}\text { Denitrification } \\
\mathrm{kg} \mathrm{ha}^{-1} \mathrm{yr}^{-1}\end{array}$ & $\begin{array}{l}\text { Nitrogen plant uptake } \\
\mathrm{kg} \mathrm{ha}^{-1} \mathrm{yr}^{-1}\end{array}$ & $\begin{array}{l}\text { Phosphorus plant uptake } \\
\mathrm{kg} \mathrm{ha}^{-1} \mathrm{yr}^{-1}\end{array}$ \\
\hline Urban Lands & 0.47 & 27.83 & 35.08 & 9.06 \\
Developed Open land & 3.35 & 6.03 & 26.01 & 6.39 \\
Agriculture & 6.59 & 11.03 & 47.37 & 12.64 \\
Cattle Field & 0.50 & 41.21 & 24.55 & 3.57 \\
Forest Lands & 10.17 & 25.33 & 21.59 & 3.51 \\
Forest Wetlands & 8.84 & 48.23 & 13.26 & 2.13 \\
Non-forest Wetlands & 5.21 & 23.2 & 32.69 & 12.62 \\
Baren Lands & 1.60 & 33.86 & 13.34 & 1.93 \\
Total & 36.74 & 216.71 & 213.89 & 51.85 \\
\hline
\end{tabular}

Third, although the simulated denitrification rates in the forested wetlands were substantially higher than any other sources (Table 4), the denitrification rate still seems to be substantially less than the observed rate of $1,200 \mathrm{~kg} \mathrm{ha}^{-1} \mathrm{yr}^{-1}$ measured in a managed riparian wetland in the Coastal Plain of North Carolina (Sloan et al., 1999). Since the forested wetlands in the NECFR watershed were not managed lands and simulated denitrification rates were only $48.23 \mathrm{~kg}$ $\mathrm{ha}^{-1} \mathrm{yr}^{-1}$, the results suggest that the natural wetlands were not capable of depleting all of the nitrate sources from the surface like the managed wetlands.

Fourth, plant uptake of $\mathrm{N}$ in the forest wetlands were comparatively lower than in agricultural and forested lands (Table 4). As a result, more $\mathrm{TN}$ entering the forested wetlands ended up in LCFR through surface and subsurface flows. Compare to forested wetland $\left(1,146.86\right.$ tons year ${ }^{-1}$ of TN), forested lands contributed less TN load (706.66 tons year ${ }^{-1}$ ) to the LCFR. The simulated TN loading rates from forested land was approximately $6.05 \mathrm{~kg} \mathrm{ha}^{-1} \mathrm{yr}^{-1}$. This result is also supported by the study conducted by Chescheir et al. (2003) in forested land in the coastal plain of eastern North Carolina. They found less than $6.5 \mathrm{~kg} \mathrm{ha}^{-1} \mathrm{yr}^{-1}$ of
TN exported from the forested watershed. So the model estimated TN loads was fairly close to their field based rate. Consequently, continuous conversion of forested land to hog farming land may tend to increase $\mathrm{TN}$ loads in the watershed.

Also, the SWAT model estimated forest biomass to be 10 tons $\mathrm{ha}^{-1}$. In Eastern USA, forest biomass density ranges widely from 2 to 346 tons $\mathrm{ha}^{-1}$ for softwood forests and from 36 to 344 tons/ha for hardwood forests (Browna et al., 1999). The NECFR watershed is comprised of mostly mixed type of forest, suggesting that the model prediction lies within the range.

Lastly, contribution of TN from urban lands, cattle grazing fields, non-forested wetlands and barren lands were substantially lower compared to forested wetlands and agricultural lands $(<10 \%)$. The small contribution could be due to the relatively smaller land area occupied by these land-uses in the watershed. These land areas covered only $1.5,4.8,0.7$ and $0.1 \%$ of the total watershed area, respectively.

\section{Total Phosphorus}

The developed open spaces, agricultural lands and forested wetlands are the dominant TP contributing non- 
point sources (Table 3). Although the developed open space covers only $3 \%$ of the watershed, it contributed $37 \%$ of the total load of 452 tons $\mathrm{yr}^{-1}$ to the LCFR from the NECFR watershed. Additionally, the agricultural lands and forested wetlands also respectively contributed 31 and $18 \%$ of the total load. Since sorption capacity of phosphorus in soil is high, major portions of these loads were due to substantial amount of sediment loads contributed from these land-uses (Table 3). As the sediment loads from other non-point sources were substantially lower, their TP contributions to the river were relatively lower (2-3\%) as well.

Like in TN, wetlands in the NECFR watershed could not decrease $\mathrm{P}$ loading to downstream aquatic systems. A mechanistic explanation of this observation is unavailable. A further study is required to understand regulation of the wetlands with respect to vegetation composition, periphyton and plankton, plant litter and detrital accumulation, soil physiochemical properties, water flow velocity, water depth, hydraulic retention time, length to width ratio, $\mathrm{P}$ loading and hydrologic functions (Reddy et al., 1999).

\section{Conclusion}

Nutrient contributions from point and nonpoint sources were identified and assed in the NECFR using the SWAT model. The SWAT model results suggested that nonpoint sources contributed more than $95 \%$ of the nutrient loads to the LCFR. Among the nonpoint sources, developed open spaces, agricultural lands and forested wetlands contributed substantial amount of sediment (61394.31 tons $\mathrm{yr}^{-1}$ ) and TP loads (294.23 tons $\left.\mathrm{yr}^{-1}\right)$. In addition, the agricultural lands, forested land and forested wetland contributed substantial amount of TN loads (2257. 65 tons $\left.\mathrm{yr}^{-1}\right)$ to the LCFR.

Since several streams/creeks drain nutrients from wetlands as well as from adjoining lands, the wetlands functioned as a passive source by transporting nutrients into streams in the natural environment. In addition, the wetlands receive higher amount of pollution input from surrounding agricultural land used for hog farming. However, the lack of research to document the relative contribution of nutrients from the hog farms to the wetlands has hindered to quantify the filtering capacity of the wetlands in this study. Nutrient reduction scenarios without considering the contribution-from wetlands could be a difficult task in this watershed. Therefore, the above findings need to be further justified by conducting a field study to understand assimilative capacity of wetlands in the watershed. Assessments of denitrification and mineralization processes in the forested wetlands are also important areas to consider for future research studies.

\section{Acknowledgement}

We would like to thank Kathy Stecker of North Carolina Division of Water Quality for her advices and editing this report and Amy Keyworth and Andy Painter for their technical assistance in GIS data operation. We extend our special thanks to Dr. Mike White and Nancy Simmons of the United State Department of Agriculture for their help in debugging modeling errors. We also extend our special thanks to Wilmington Regional Office and Lower Cape Fear River Technical Advisory Group for their helpful suggestions in data collection and analysis.

\section{Funding Information}

We would like to thank the Division Water Quality (currently named as Division of Water Resources) for providing logistics support to develop this manuscript.

\section{Author's Contributions}

Narayan B. Rajbhandari: Study design, data collection, data analysis, model selection, model set up, calibration and validation, manuscript development.

Sushama Pradhan: Model set up, data analysis and manuscript development.

Mauro Di Luzio: Model set up, model verification.

Adugna Kebede: Model performance, manuscript development.

Virginia Baker: Data interpretation, manuscript development.

\section{References}

Arnold, J.G., R. Srinivasan, R.S. Muttiah and J.R. Williams, 1998. Large area hydrologic modeling and assessment part I: Model development. J. Am. Water Resource Assoc., 34: 73-89.

DOI: 10.1111/j.1752-1688.1998.tb05961.x

Borah, D.K., G. Yagow, A. Saleh, P.L. Barnes and W. Rosenthal et al., 2006. Sediment and nutrient modeling for TMDL development and implementation. Trans. ASABE, 49:967-986. DOI: $10.13031 / 2013.21742$

Browna, S.L., P. Schroederb and J.S. Kernb, 1999. Spatial distribution of biomass in forests of the eastern USA. Forest Ecol. Manage., 123: 81-90. DOI: 10.1016/S0378-1127(99)00017-1

Busteed, P.R., D.E. Storm, M.J. White and S.H. Stoodley, 2009. Using SWAT to target critical source sediment and phosphorus areas in the Wister lake basin, USA. Am. J. Environ. Sci., 5: 156-163. DOI: 10.3844/ajessp.2009.156.163 
Cahoon, L.B., J.A. Mikucki and M.A. Mallin, 1999. Nitrogen and phosphorus imports to the cape fear and Neuse river basins to support intensive livestock production. Environ. Sci. Technol., 33: 410-415. DOI: $10.1021 / \mathrm{es} 9805371$

Chescheir, G.M., M.E. Lebo, D.M. Amatya, J. Hughes and J.W. Gilliam et al., 2003. Hydrology and water quality of forested lands in Estern North Carolina. Technical Bulletin 320, North Carolina State University, Raleigh. NC.

Dahlen, P.R. and R.M. Milosh, 2002. Impact of animal waste lagoons on ground water quality: An update on data collected from March 1998 through November 1999. Report of Groundwater Investigation Number 18, NC Department of Environment and Natural Resources. Raleigh, NC.

Glysson, G.D., J.R. Gray and L.M. Conge, 2004. Adjustment of total suspended solids data for use in sediment studies. American Society of Civil Engineering.

Graves, G.A., Y. Wan and D.L. Fike, 2004. Water quality characteristics of storm water from major land uses in south Florida. J. Am. Water Resources Assoc., 40: 1405-1419. DOI: $10.1111 / \mathrm{j} .1752-1688.2004 . t b 01595 . \mathrm{x}$

Hendrickson, J., N. Trahan, E. Gordon and Y. Ouyang, 2007. Estimating relevance of organic carbon, nitrogen and phosphorus loads to a blackwater River Estuary. J. Am. Water Resources Assoc., 43: 264-279. DOI: $10.1111 / \mathrm{j} .1752-1688.2007 .00021 . x$

Jha, M.K., P.W. Gassman and J.G. Arnold, 2007. Water quality modeling for the Raccoon River watershed using SWAT. Trans. ASABE, 50: 479-493. DOI: $10.13031 / 2013.22660$

Johnston, C.A., 1991. Sediment and nutrient retention by freshwater wetlands: Effects on surface water quality. Critical Rev. Environ. Control, 21: 491-565. DOI: 10.1080/10643389109388425

Kirsh, J., A. Kirsh and J.G. Arnold, 2002. Predicting sediment and phosphorus loads in the Rock River basin using SWAT. Trans. ASAE, 45: 1757-1769.

Mallin, M.A., J.M. Burkholder, M.R. McIver, G.C. Shank and H.B. Glasgow et al., 1997. Comparative effects of poultry and swine waste lagoon spills on the quality of receiving stream waters. J. Environ. Quality, 26:1622-1631. DOI: $10.2134 /$ jeq1997.00472425002600060023x

Mallin, M.A., 2000. Impact of industrial animal production on rivers and estuaries. Am. Scientist, 88: 2-13.

Mallin, M.A., L.B. Cahoon, D.C. Persons and S.H. Ensign, 2001. Effect of nitrogen and phosphorus loading in Coastal plain blackwater rivers. J. Freshwater Ecol., 16: 455-466. DOI: $10.1080 / 02705060.2001 .9665832$
Meyer, J.L., 1990. A blackwater perspective on riverine ecosystems: Ecologists are taking a broader view of streams and their food webs. BioScience, 40: 643-651. DOI: $10.2307 / 1311431$

Moran, M.A., W.M. Sheldon, Jr. and J.E. Sheldon, 1999. Biodegradation of riverine dissolved organic carbon in five estuaries of the southeastern United States. Estuaries, 22: 55-64. DOI: 10.2307/1352927

Moriasi, D.N., J.G. Arnold, M.W. Van Liew, R.L. Bingner and R.D. Harmel et al., 2007. Model evaluation guidelines for systematic quantification of accuracy in Watershed Simulations. Am. Society Agric. Biol. Eng., 50: 885-900.

Niraula, R., L. Kalin, R. Wang and P. Srivastava, 2012. Determining nutrient and sediment critical source areas with SWAT: Effect of lumped calibration. Trans. ASAE, 55: 137-147.

DOI: $10.13031 / 2013.41262$

NCDA\&CA, 2007. Agricultural statistics-census of agriculture. North Carolina Department of Agriculture and Consumer Services.

NCDENR, 2007. North Carolina water quality assessment and impaired waters list. 2006 Integrated 305(b) and 303(d) Report. North Carolina Department of Environment and Natural Resources, Division of Water-Resouces, Raleigh, NC.

Neitsch, S.L., J.G. Arnold, J.R. Kiniry, R. Srinivasan and J.R. Williams, 2002. Soil and water assessment tool. Texas Water Resources Institute, College Station, Texas.

Ouyang, W., F.H. Hao and X.L. Wang, 2008. Regional non point source organic pollution modeling and critical area identification for watershed best environmental management. Water Air Soil Poll., 187: 251-261. DOI: 10.1007/s11270-007-9513-y

Reddy, K.R., R.H. Kadlec, E. Flaig and P.M. Gale, 1999. Phosphorus retention in streams and wetlands: A review. Critical Rev. Environ. Sci. Technol., 29: 83-146. DOI: $10.1080 / 10643389991259182$

Savage, R. and V. Baker, 2007. Development of a headwater monitoring program for headwater wetlands in North Carolina - water quality analysis. Final Report, NC Department of Environment and Natural Resources, Division of Water Quality, Wetland Program Development Unit.

Saunders, D.L. and J. Kalff, 2001. Nitrogen retention in wetlands, lakes and rivers. Hydrobiologia, 443: 205-212. DOI: 10.1023/A:1017506914063

Seitzinger, S.P., R.W. Sanders and R. Styles, 2002. Bioavailability of DON from natural and anthropogenic sources to estuarine plankton. Limnol. Oceanography, 47: 353-366.

DOI: $10.4319 /$ lo.2002.47.2.0353 
Shah, S.B., G.L. Grabow, R.L. Huffman, D.L. Hesterberg and D.H. Hardy et al., 2006. Arsenic and heavy metal leaching potential from turkey litter stockpiled on bare soil. Report No. 371. UNC Water Resources Research Inst., Raleigh, NC.

Sloan, A.J., J.W. Gilliam, J.E. Parsons, R.L. Mikkelsen and R.C. Riley, 1999. Groundwater nitrate depletion in a swine lagoon effluent-irrigated pasture and adjacent riparian zone. J. Soil Water Conser., 4: 651-656.

Smock, L.A. and E. Gilinsky, 1992. Coastal Plain Blackwater Stream: P271-311. In: Biodiversity of the Southeastern United States, C.T. Hackney, S.M. Adams and W.H. Martin (Eds.), John Wiley and Sons, Inc. New York.

UIUC. 2007. National atmospheric deposition program. UIUC.

USDA, 2004. 2002 Census of agriculture (North Carolina state and county data). U.S. Department of Agriculture.
USEPA, 1999. Technical guidance manual for performing waste load allocations, book III estuaries, Part 2. Application of Estuarine Waste Load Allocation Models, U.S. Environmental Protection Agency.

Veith, T.L., A.N. Sharpley, J.L. Weld and W.J. Gburek, 2005. Comparison of measured and simulated phosphorus losses with indexed site vulnerability. Trans. ASAE, 48: 557-565. DOI: $10.13031 / 2013.18330$

Wischmeier, W.H. and D.D. Smith, 1978. Predicting rainfall erosion losses-a guide to conservation planning. Agricultural Handbook 537, U.S. Department of Agriculture, Washington, DC.

Winchell, M., R. Srinivasan, M. DiLuzio and J. Arnold, 2009. ArcSWAT 2.3.4 Interface for SWAT2005. User's guide. Blackland Research Center, TX Agricultureal Experiment Stateion, 720 East Blackland Road -Temple, TX 76502. 